\title{
Vínculos entre la Merced y las hermandades penitenciales en la provincia de Sevilla. Notas sobre su historia y patrimonio
}

\author{
Ties between la Merced and the penitential \\ confraternities in the province of Seville. \\ Notes on their history and heritage
}

\author{
$\mathbf{M}^{\text {a Teresa Ruiz Barrera }}$ \\ Doctora en Historia del Arte \\ ID ORCID 0000-0001-5391-9510
}

\begin{abstract}
Resumen: Exponemos en el artículo una breve relación de las diez hermandades penitenciales que, nacidas entre los siglos XVI y XX, se relacionan con la orden de la Merced o de la Merced Descalza en la provincia sevillana. Completamos el estudio con aquellas que presentan, por diversas causas, iconografía propia de la orden, pero que no nacieron bajo el auspicio de algunas de las dos órdenes redentoras.
\end{abstract}

Palabras clave: hermandad, Merced, Merced Descalza, Benacazón, Bollullos de la Mitación, Écija, Estepa, Fuentes de Andalucía, Marchena, Morón de la Frontera, Osuna, ElViso del Alcor.

\begin{abstract}
Abstrac: In the article we present a brief list of the ten penitential brotherhoods that were borned between the centuries $X V I$ and $X X$, and are related with the Mercedarian Order or the Merced Descalza in the province of Seville. We complete the study with those that, due to different reasons, present their own iconography, but that did not arise with the patronage of any of the two redeeming orders?
\end{abstract}

Keywords: Brotherhood, Merced, Merced Descalza, Benacazón, Bollullos de la Mitación, Écija, Estepa, Fuentes de Andalucía, Marchena, Morón de la Frontera, Osuna, ElViso del Alcor.

\section{INTRODUCCIÓN}

Las órdenes religiosas fueron los principales centros de espiritualidad que expandieron la devoción hacia la Virgen alcanzando gran difusión a partir de la Edad Media en Europa. A ellas hay que unir las 
hermandades y cofradías que se convirtieron en el otro gran vehículo para encauzar la religiosidad popular ${ }^{1}$.

Las relaciones entre la Merced y la Merced Descalza y las hermandades o cofradías letíficas o penitenciales existen principalmente porque nacieron en los conventos - tomando a veces la advocación de la Virgen de la Merced como su cotitular - o se acogieron a ellos².

En la provincia de Sevilla son diez las hermandades penitenciales más tres letíficas, estas últimas ya expuestas en otros estudios ${ }^{3}$. Son nueve las localidades en las que se encuentran. Circunscribo el presente estudio a las primeras corporaciones destacando algunas noticias sobre su historia, titulares y enseres más destacados, ejemplos de todas las bellas artes.

\section{HERMANDADES RELACIONADAS CON LA MERCED POR LA ADVOCACIÓN DE SU COTITULAR MARIANA}

\subsection{Fuentes de Andalucía. «Pontificia, Ilustre, Sacramental y Muy Antigua Hermandad y Cofradía de Nuestro Padre Jesús Nazareno, Santa Cruz en Jerusalén y Nuestra Señora de la Merced».}

Fue fundada a finales del siglo XVI, tal vez en la parroquia de Santa María la Blanca, pero se trasladó a la iglesia del ex - convento descalzo de San José a finales de 1616 o principios de $1617^{4}$. Dicho con-

1 HERNÁNDEZ GONZÁLEZ, Salvador, “Devociones marianas de gloria y órdenes religiosas en Andalucía", en XX Simposio Advocaciones marianas de Gloria. San Lorenzo del Escorial, Instituto Escurialense de Investigaciones Históricas y Artísticas, 2012, pp. 107-120.

2 RUIZ BARRERA, M. ${ }^{a}$ Teresa,"Merced Dolorosa". El neobarroco sevillano en sus imágenes", en Congreso Internacional Actas. Orden de los Siervos de María. Fraternidad de la Bienaventurada Virgen María Dolorosa. Carmona, 2016, pp. 1273-1288. ID., "Nuestra Señora de la Merced en el Patrimonio artístico de las Hermandades de Penitencia de Sevilla", en Estudios n 203, 1998, pp. 18-19.

3 RUIZ BARRERA, M. a Teresa, "Auge, ocaso y pervivencia de Hermandades mercedarias de Gloria. Devoción, historia y arte en la archidiócesis de Sevilla", en Anuario de Historia de la Iglesia andaluza Vol.VIII. Sevilla, 2015, pp. 216-217. 224225. 238-241.

4 PASTOR TORRES, Álvaro, "Pontificia, Ilustre, Sacramental y Muy Antigua Hermandad y Cofradía de Nuestro Padre Jesús Nazareno, Santa Cruz en Jerusalén y Nuestra Señora de la Merced", en SÁNCHEZ HERRERO, José, José 
vento de mercedarios descalzos se fundó en 1608 por don Gome de Fuentes y Guzmán, I marqués de Fuentes, cumpliendo la voluntad de su difunta madre doña Aldonza de los Ríos Acevedo y Mendoza, y con la mediación de don Andrés Gamero Adalid, beneficiado, vicario y comisario del Santo Oficio en la villa de Fuentes ${ }^{5}$. Tras las vicisitudes históricas que obligaron a la hermandad a varios cambios de sedes, retornó a la ex-iglesia conventual, ya restaurada, elViernes de Dolores 6 de abril de 2001.

La imagen titular de Nuestro Padre Jesús Nazareno es obra anónima de la escuela sevillana de finales del siglo XVII ${ }^{6}$. Nuestra Señora de la Merced es, también, de autoría anónima y se adscribe al siglo XVIII. Su dolorido rostro expresa unción religiosa y gran angustia patente en las dos lágrimas que se deslizan por ambas mejillas; ceño fruncido, cejas bien marcadas, ojos pintados, nariz recta y bien modelada y labios entreabiertos, así como sus expresivas manos ${ }^{7}$.

El escudo mercedario consta de dos partes: en la superior ostenta una gran cruz blanca, símbolo del capítulo de la Seo de Barcelona, sobre fondo rojo y en la parte inferior, barras de gules rojas sobre campo de oro. Es el motivo iconográfico más numeroso, pues forma parte de la heráldica de varias de las hermandades a estudiar, como es el caso de la que nos ocupa.

Luce bordado en el estandarte, obra de J. Cobos realizada en 1992 y en el paño de bocina, ejecutado por un grupo de hermanas de la

RODA PEÑA y Federico GARCÍA DE LA CONCHA DELGADO, Nazarenos de Sevilla. T. II. Sevilla, Tartessos, 1997, p. 278.

5 SAN CECILIO, Pedro de, O.M.D., Annales del Orden de Descalzos de Ntra. Sra. de la Merced Redempcion de Cautivos. (Barcelona 1618). Madrid, 1985, T. II, pp. 645-646.

6 PASTOR TORRES, Á.,"Pontificia, Ilustre, Sacramental y Muy Antigua Hermandad y Cofradía de Nuestro Padre Jesús Nazareno, Santa Cruz en Jerusalén y Nuestra Señora de la Merced", op. cit., T. II, pp. 278. 280. Se restauró en 1992 por Luis Lagares y José Rioja, p. 283.

7 PASTOR TORRES, Á., "Pontificia, Ilustre, Sacramental y Muy Antigua Hermandad y Cofradía de Nuestro Padre Jesús Nazareno, Santa Cruz en Jerusalén y Nuestra Señora de la Merced", op. cit., T. II, pp. 281-283. RUIZ BARRERA, M. ${ }^{\text {a T., La Virgen }}$ de la Merced. Iconografía en Sevilla, en Estudios 217-219 (2002) 121. ID., "Merced Dolorosa". El neobarroco sevillano en sus imágenes", op. cit., p. 1274. La imagen mariana ha sido restaurada a principios de 2020 por don Antonio Gamero Osuna y don Agustín Martín de Soto, según información oral de don Francisco J. González Fernández, cronista oficial de Fuentes de Andalucía. 


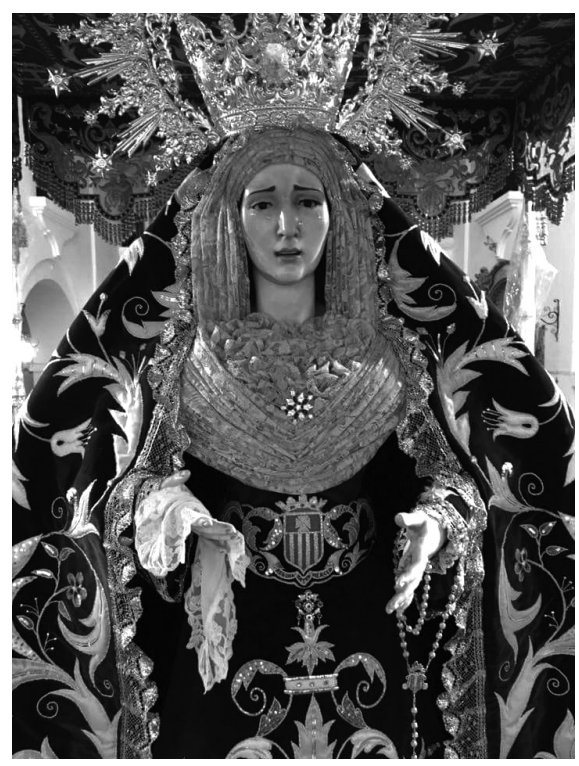

Lámina 1. Fuentes de Andalucía. Hermandad de Nuestro Padre Jesús Nazareno y Nuestra Señora de la Merced. Fajín. Taller de Jesús Carmona. 2012.

corporación, un año después ${ }^{8}$. Desde las reglas aprobadas el 26 de julio de 2005 dicho escudo de la orden se ha incluido al de la corporación. Este está formado por dos óvalos envueltos por una rama de laurel y timbrado con la corona de la villa; el de la izquierda presenta las letras doradas JHS sobre fondo morado, y el de la derecha muestra el escudo mercedario sobre color rojo ${ }^{9}$.

Se halla también en el paso del Señor, realizado por el tallista don Pedro Manuel Benítez Carrión; estrenado, en parte, en 2004 se fue completando hasta 2007 y tres años más tarde, en 2010, se realizaron las cartelas de la parte posterior $^{10}$. El escudo mercedario se integra también en la bambalina central del palio y en un faldón delantero, obra de los Talleres ecijanos de Jesús Carmona, ejecutada en 2009; igualmente lo hallamos en una joya que se prende en el pecherín mariano, donado por doña Rosario Barcia Caro en la década de $1990^{11}$; bordado en un pañuelo, regalo del pregonero de la Semana Santa de 2008, don Francisco J. González Fernández y, bordado a color entre los hilos de oro del

8 PASTOR TORRES, Á., "Pontificia, Ilustre, Sacramentaly Muy Antigua Hermandad y Cofradía de Nuestro Padre Jesús Nazareno, Santa Cruz en Jerusalén y Nuestra Señora de la Merced", op. cit., T. II, p. 283.

9 PASTOR TORRES, Á., "Pontificia, Ilustre, Sacramental y Muy Antigua Hermandad y Cofradía de Nuestro Padre Jesús Nazareno, Santa Cruz en Jerusalén y Nuestra Señora de la Merced", op. cit., T. II, p. 281.

10 https://jesusnazarenofuentes.es.

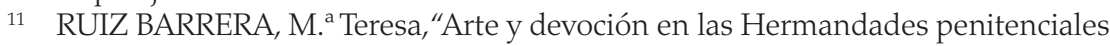
mercedarias de la provincia de Sevilla", en Morón Cofrade 13 (2010) 74. 
fajín, realizado en 2012 por el taller de Jesús Carmona, quien además lo donó (Lám. 1) ${ }^{12}$.

\subsection{Bollullos de la Mitación. «Ilustre y Fervorosa Hermandad de Nuestra Señora de Roncesvalles y Cofradía de Nazarenos de Nuestro Padre Jesús del Gran Poder y María Santísima de la Merced en su Amargura»}

La corporación nació el 29 de abril de 1949. Desde su principio tiene su sede canónica en la Capilla de la Virgen de Roncesvalles ${ }^{13}$. El párroco y los hermanos fundadores eligieron dos advocaciones marianas que, desde ese momento, quedaron unidas en el nombre de su cotitular dolorosa: Merced o Misericordia y Amargura. Fue coronada en 30 de noviembre de 1959. La actual dolorosa es una hermosa imagen obra de Luis Álvarez Duarte, quien la realizó en 2002. Posee un rostro caracterizado por una serena expresión y dolor contenido, a la vez íntimo y visible por las seis lágrimas que se deslizan por sus meji1 las ${ }^{14}$. Anteriormente la hermandad tuvo como representación mariana tres imágenes. La primera, fue una Inmaculada Concepción que se conservaba en la parroquia y que rápidamente se transformó en dolorosa para la procesión de 1949. Las dos siguientes fueron obra de Antonio Ruiz (1918-2001), co-fundador de la corporación que era escultor e imaginero natural de esa localidad. La primera fue un boceto de una imagen a tamaño natural con mascarilla y manos en barro cocido y policromado, material escogido por la premura del encargo, pues los hermanos deseaban que procesionara el mismo año de

12 Mi agradecimiento a don Francisco J. González Fernández por su interés e información.

13 RODRÍGUEZ BABÍO, Amparo, "Ilustre y Fervorosa Hermandad de Nuestra Señora de Roncesvalles y Cofradía de Nazarenos de Nuestro Padre Jesús del Gran Poder y María Santísima de la Merced en su Amargura", en SÁNCHEZ HERRERO, José, José RODA PEÑA y Federico GARCÍA DE LA CONCHA DELGADO, Nazarenos de Sevilla. T. II. Sevilla, Tartessos, 1997, pp. 70-71. 75.

14 RUIZ BARRERA, M. a T., La Virgen de la Merced. Iconografía en Sevilla, en op. cit., pp. 123-124. Procesiona desde 2003, JOAQUÍN LEÓN, José, El niño imaginero. Medio siglo de cofradías con Álvarez Duarte, Sevilla 2014³, pp. 213-214. RUIZ BARRERA, M. ${ }^{a}$ T., "Merced Dolorosa. El Neobarroco sevillano en sus imágenes", op. cit., p. 1278. 
195015. La segunda la realizó entre 1986 y 1897 y, por deseo expreso de la corporación penitencial, poseía rasgos fisonómicos muy similares a los de Nuestra Señora de la Esperanza Macarena de Sevilla ${ }^{16}$. Es esta la que preside el Libro de Reglas, pintada por el mismo artista en 1989 ${ }^{17}$. La talla de Nuestro Padre Jesús del Gran Poder fue también realizada por el citado imaginero en $1958^{18}$.

El emblema mercedario lo hallamos en los respiraderos de ambos pasos, en el del Señor, son los antiguos del Dulce Nombre de Sevilla, y en el paso de palio, labrado por Jesús Domínguez en 1970; en la peana de plata que realizara Juan Fernández, en la década de 1970; en la candelería, por Hijos de Juan Fernández, en 1978. Asimismo, se aprecia en las dos coronas marianas: en la de oro - obra de E. García Armenta, de 1958 - y en la de plata, del orfebre Jesús Domínguez, del año 2000; la imagen también lo luce en un broche de oro y rubíes, trabajo hecho por Joyería Purísima, en el mismo año; y en los dos puñales, el de plata realizado en 1985 por Emilio García Armenta y en el de oro, obra fechada en 2010. Estos ejemplos concluyen con el escudo de la Merced en la cubierta del Libro de Reglas, de 1989.

Bordado se aprecia en el Simpecado, obra del Taller de San Luis, de 1950; en el guión, realizado en 1980; en los paños de las bocinas, de la misma fecha; en el estandarte (diseño de Francisco Manuel Sigueredo López) confeccionado por Benjamín Pérez, en el mismo año de 1980; en la bambalina frontal del palio, obra en terciopelo rojo de Talleres de Mairena del Aljarafe y enriquecido con oro por Talleres de Fernández y Enríquez de Brenes; el escudo en sí es diseño de Antonio Pérez y ha sido renovado por el Taller de Brenes, en 2009; también lo hallamos en la toca de sobremanto y en la saya de

15 Medía $145 \mathrm{~cm}$. Una vez retirada del culto le fue entregada al artista, RUIZ BARRERA, M. ${ }^{a}$ T., La Virgen de la Merced. Iconografía en Sevilla, op. cit., p. 124.

16 Mide 1,59 m. RODRÍGUEZ BABÍO, A., "Ilustre y Fervorosa Hermandad de Nuestra Señora de Roncesvalles y Cofradía de Nazarenos de Nuestro Padre Jesús del Gran Poder y María Santísima de la Merced en su Amargura", op. cit., t. II, p. 70. RUIZ BARRERA, M. ${ }^{a}$ T., La Virgen de la Merced. Iconografía en Sevilla, op. cit., p. 123. ID., Descubriendo Andalucía. El arte mercedario en Sevilla (Biblioteca mercedaria. Documenta et Studia, III/2), Roma 2008, p. 149.

17 Mide $28 \times 22$ cm., RUIZ BARRERA, M. ${ }^{a}$ T., Descubriendo Andalucía. El arte mercedario en Sevilla, op. cit., pp. 150. 148.

18 RODRÍGUEZ BABÍO, A., "Ilustre y Fervorosa Hermandad de Nuestra Señora de Roncesvalles y Cofradía de Nazarenos de Nuestro Padre Jesús del Gran Poder y María Santísima de la Merced en su Amargura", op. cit., T. II, p. 70. 
la Virgen, ambas ejecutadas por Fernández y Enríquez en 1992 y en 2009, respectivamente ${ }^{19}$.

En cuanto al arte escultórico a más de su cotitular, desde 2016 lucen en el paso de palio unas figuras de san Pedro Nolasco (Lám. 2) y san Ramón Nonato, obras de Fernando del Toro. Ambas efigies, realizadas en plata y marfil en rostro y manos, los representan en actitud erguida e itinerante como hombres de faz madura y barbada. Cada uno luce sus atributos más característicos. El fundador sostiene en su mano derecha el lábaro de la orden, en la izquierda un cepo de grilletes, antítesis de la redención de cautivos a la que se dedicaba la orden mercedaria, y a sus pies, cruz patriarcal y libro. Por su parte, el primer cardenal de la Merced muestra un candado sellando sus labios, en recuerdo

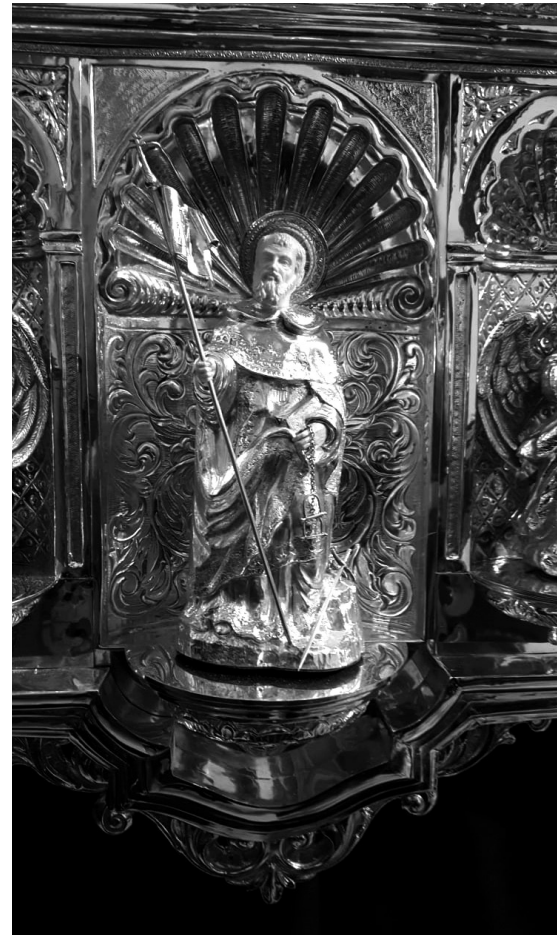

Lámina 2. Bollullos de la Mitación. Hermandad de N. P. Jesús del Gran Poder y María Santísima de la Merced en su Amargura. San Pedro Nolasco. Fernando del Toro. 2016.

del martirio no mortal que sufrió por predicar el Evangelio mientras estaba cautivo en Argel; un ostensorio en su diestra - por su devoción al misterio de la Eucaristía -, y la habitual palma de martirio con triple corona en su izquierda, en relación a su condición de virgen, confesor y mártir, mientras a sus pies yace un capelo

19 RUIZ BARRERA, M. ${ }^{a}$ T., "Arte y devoción en las Hermandades penitenciales mercedarias de la provincia de Sevilla", op. cit., pp. 75-76. Algunos enseres se citan en RODRÍGUEZ BABÍO, A., "Ilustre y Fervorosa Hermandad de Nuestra Señora de Roncesvalles y Cofradía de Nazarenos de Nuestro Padre Jesús del Gran Poder y María Santísima de la Merced en su Amargura de Bollullos de la Mitación,"op. cit., p. 75. 
cardenalicio, símbolo de su renuncia a dicha dignidad, aunque tuvo que obedecer y aceptarla ${ }^{20}$.

\subsection{Marchena. «Asociación de Nuestro Padre Jesús de la Salud Cautivo, Madre de Dios de la Merced, Redentora de cautivos y Santo Niño de la Misericordia»}

Nace en 2006 en la iglesia parroquial de san Miguel, regentada por el mercedario descalzo, P. fray Tomás Javier Gago, del convento de san Agustín. Marco Antonio Humanes López, imaginero natural de la localidad, realizó en el mismo año en cedro policromado al óleo la imagen de la Virgen, caracterizada por un hermoso y juvenil rostro de facciones ovaladas que se gira levemente hacia su izquierda; presenta cejas suavemente arqueadas y bien moldeadas, marcado entrecejo que ahonda en la expresión dolorida junto con la mirada que reflejan los pequeños y almendrados ojos verdes - muy realistas con las pestañas postizas -, nariz

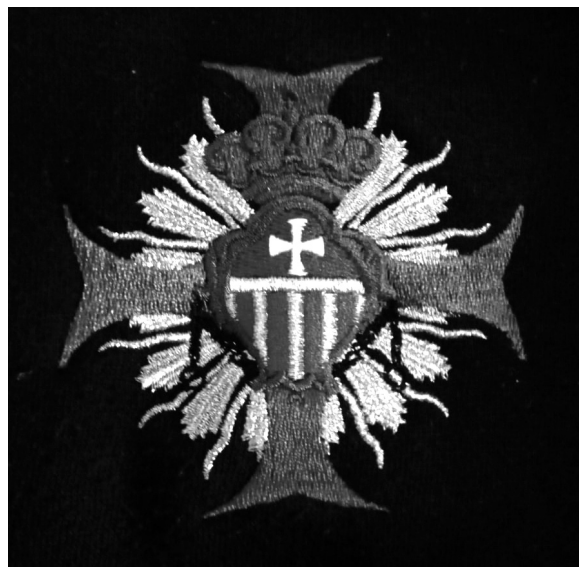

Lámina 3. Marchena. Asociación de Nuestro Padre Jesús de la Salud Cautivo y Madre de Dios de la Merced, Redentora de cautivos. Estandarte. Grupo Joven, 2006. recta y boca que, al entreabrirse, deja ver la lengua y los dientes superiores tallados. Como símbolo del dolor el artista desliza tres lágrimas en forma asimétrica: una recorre su mejilla derecha y las restantes la izquierda, y son de larga singladura en su rostro, lo que incide en el dolor que emana de él. La talla se extiende a la cabellera, negra y ondulada, que se recoge en un moño bajo. Las manos son naturalistas ${ }^{21}$. Sus manos, con las palmas extendidas, presentan una ligera flexión del dedo índice, acentuándose esta en los

20 RUIZ BARRERA, M. ${ }^{a}$ T., "La Merced en los"Pasos" penitenciales. Algunos ejemplos en Andalucía Occidental", en Arte, cultura y patrimonio. II Congreso Nacional. Zamora, Ayuntamiento de Zamora, 2019, pp. 579. 580.

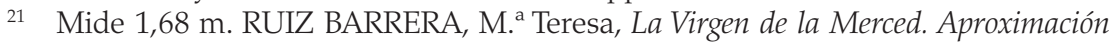
a su iconografía en Sevilla no 26-27, 2007-2008, p. 113. Lám. 53. ID., "Merced Dolorosa. El Neobarroco sevillano en sus imágenes", op. cit., p. 1278. 
dedos corazón y anular, para asir pañuelo y rosario. Talló a Nuestro Padre Jesús de la Salud, en el mismo tipo de madera y técnicas, en 2011, representándole como Jesús Cautivo en el monte de los olivos.

Hallamos el escudo mercedario, integrado en el de la corporación y por ello luce bordado en el estandarte o «bacalao», de raso blanco (Lám. 3) y en los respiraderos del paso del Señor Cautivo, tallados en madera dorada. Ambas piezas fueron realizadas por el Grupo Joven en los años 2006 y 2014, respectivamente ${ }^{22}$.

\section{HERMANDADES NACIDAS EN LOS CONVENTOS MERCEDARIOS O EN SUS ANTIGUOS TEMPLOS}

\section{1. Écija. «Hermandad de Nuestra Señora de la Piedad y Santísimo Cristo de la Exaltación en la Cruz»}

Las primeras reglas conocidas se aprobaron en 1567, aunque debió nacer la corporación en décadas anteriores, pues ya existía en 1543, organizada en torno a la primitiva imagen de Nuestra Señora de la Piedad (la actual es obra anónima de mediados del siglo XVIII, donada por fray José de la Escalera en 1751). Más tarde se contrató la talla del Santísimo Cristo de la Exaltación en 1597 con Miguel deVilches ${ }^{23}$. Su sede canónica es el templo del antiguo convento mercedario fundado en $1509^{24}$, aunque desde marzo de 2019 provisionalmente se halla en la iglesia prioral de santa María debido al mal estado de conservación de las cubiertas del edificio religioso. Como heredera de los bienes del templo da culto a una antigua imagen mariana, titular del convento ${ }^{25}$.

22 La asociación se halla en proceso de constituirse en hermandad. Por error en informaciones orales anteriores a esta publicación se nombra a la asociación como agrupación parroquial. Agradezco a don Amalio Narváez, presidente de dicha asociación, la información recibida y su interés en el presente estudio.

23 MARTÍN OJEDA, Marina y Gerardo GARCÍA LEÓN, "Hermandad de Nuestra Señora de la Piedad y Santísimo Cristo de la Exaltación en la Cruz", en SÁNCHEZ HERRERO, José, José RODAPEÑAy Federico GARCÍA DE LA CONCHA DELGADO (coord.). Crucificados de Sevilla. T. III. Sevilla, Tartessos, 2002, pp. 376. 382-383.

24 RUIZ BARRERA, M. ${ }^{a}$ Teresa, "La Orden de Santa María de la Merced Redención de cautivos cristianos" en, M. ${ }^{a}$ T. RUIZ BARRERA y N. PÉREZ-AÍNSUA MÉNDEZ, La Orden de la Merced en Écija (siglos XVI-XXI), Biblioteca Ecijana n ${ }^{\circ}$, Écija, Asociación Cultural Ecijana «Martín de Roa», 2007, p. 25.

25 HERNÁNDEZ DÍAZ, José, Antonio SANCHO CORBACHO y Francisco COLLANTES DE TERÁN, Catálogo arqueológico y artístico de la provincia de 
Como en otras corporaciones penitenciales el escudo de la orden forma parte del emblema de la hermandad de la Piedad. Así se nos muestra en los respiraderos del paso del Santísimo Cristo de la Exaltación en la Cruz, obra de Villarreal, realizada entre 1974 y 1978; y en los faroles y los candelabros, del mismo autor en 1992. Luce en las bambalinas bordado por Joaquín Ojeda, entre 1980 y 1987; en los faldones del palio por Jesús Rosado, en 1986; y en el estandarte y en el banderín, ejecutados en 2009 por Antonio Pardal26

\subsection{Osuna. «Real Hermandad de Penitencia y Humilde Esclavitud Mercedaria de N. P. Jesús Caído, Benditas Ánimas del Purgatorio y Cofradía de Nazarenos de las Negaciones y Lágrimas del Señor san Pedro y Nuestra Señora y Madre de los Dolores»}

De la antigua Esclavitud de Nuestra Santísima Madre de la Merced Redención de Cautivos Cristianos se conservan en el archivo arzobispal hispalense unas Constituciones decimonónicas, producto de un intento de revitalizarla. Su sede era el templo del convento masculino descalzo de la villa ducal ${ }^{27}$. Creo muy probable que esta esclavitud acabara integrándose en la hermandad penitencial nacida en 31 de enero de 1705. La hermandad estuvo hasta 1964 en el convento y desde entonces tiene su sede en el templo de Santo Domingo.

Nuestro Padre Jesús Caído es obra de Alonso Gayón, de $1703^{28}$, y Nuestra Señora y Madre de los Dolores, pertenece a la escuela

Sevilla. T. III. Sevilla, 1951, p. 175. Como titular del convento lo era también de la Esclavitud de seglares fundada en 15 de noviembre de 1722, RUIZ BARRERA, M. ${ }^{a}$ T., "La Orden de Santa María de la Merced Redención de cautivos cristianos", op. cit., p. 71. ID., "El convento de Nuestra Señora de la Merced, 500 años de presencia en Écija", en Actas de las VIII Jornadas de Protección del Patrimonio Histórico de Écija. 500 aniversario de la Fundación del Convento de Nuestra Señora y de la Merced y la Hermandad de Nuestra Señora de la Piedad y Stmo. Cristo de la Exaltación en la Cruz de Écija". Écija, 2 y 3 de octubre de 2009, Écija, 2010, pp. 27-70.

26 MARTÍN OJEDA, M. y G. GARCÍA LEÓN, “Hermandad de Nuestra Señora de la Piedad y Santísimo Cristo de la Exaltación en la Cruz", op cit., T. III, pp. 376. 382. 384. RUIZ BARRERA, Ma .T., "Arte y devoción en las Hermandades penitenciales mercedarias de la provincia de Sevilla", op. cit., p. 74.

27 RUIZ BARRERA, M. ${ }^{\text {a }}$ T., “Auge, ocaso y pervivencia de Hermandades mercedarias de Gloria. Devoción, historia y arte en la archidiócesis de Sevilla”, op. cit., pp. 227-228.

28 PASTOR TORRES, Álvaro, "Real Hermandad de Penitencia y Humilde Esclavitud Mercedaria de Nuestro Padre Jesús Caído, y Benditas Ánimas del Purgatorio y 
malagueña dieciochesca a decir de Hernández González y Gutiérrez Núñez $^{29}$. Es la hermandad que posee los enseres de mayor antigüedad. Destacan dos varas fundacionales de h. 1700 o la cruz de guía, de 1705, realizada con incrustaciones de espejos y motivos de rocalla que rodean el emblema de la orden religiosa. Ambas son de autoría anónima ${ }^{30}$. El escudo de la orden mercedaria descalza luce en los ciriales, labrados por Hermanos Fernández en 2008; y bordado en la bambalina, en el faldón frontal del paso de palio, en los paños de las bocinas y en el estandarte, obra confeccionada a base de hilos de oro sobre fondo carmesí, obra de las MM. Carmelitas de san Pedro de Osuna, en la década de 1950 ${ }^{31}$. En 2011 un hermano donó a la corporación una argéntea imagen mariana, sedente, obra de Javier Fernández Buzón ${ }^{32}$.

\subsection{El Viso del Alcor. «Muy Antigua, Fervorosa y Mercedaria Hermandad y Cofradía de Nuestro Padre Jesús Nazareno, María Santísima del Mayor Dolor y Traspaso, San Juan Evangelista y Nuestra Señora de la Merced»}

Se origina a finales del siglo XVII en el propio convento descalzo del Corpus Christi, en cuya ex - iglesia sigue residiendo ${ }^{33}$. La talla del

Cofradía de Nazarenos de las Negaciones y Lágrimas del Señor San Pedro y Nuestra Señora y Madre de los Dolores", en SÁNCHEZ HERRERO, J., J. RODA PEÑA y F. GARCÍA DE LA CONCHA DELGADO (coord.). Nazarenos de Sevilla. T. III. Sevilla, Tartessos, 1997, p. 154.

29 HERNÁNDEZ GONZÁLEZ, Salvador y Francisco Javier GUTIÉRREZ NÚÑEZ, "Una aportación documental a la historia de la Hermandad de Jesús Caído de Osuna: en torno a la cronología y posible autoría de laVirgen de los Dolores", en III Jornadas de Historia sobre el Provincia de Sevilla Sierra Sur. Sevilla, Asociación Provincial Sevillana de Cronistas e Investigadores Locales, 2006, pp. 286-288.

30 PASTOR TORRES, Á., "Real Hermandad de Penitencia y Humilde Esclavitud Mercedaria de Nuestro Padre Jesús Caído, y Benditas Ánimas del Purgatorio y Cofradía de Nazarenos de las Negaciones y Lágrimas del Señor San Pedro y Nuestra Señora y Madre de los Dolores", en op. cit., T. III. pp. 148. 155.

31 RUIZ BARRERA, M. ${ }^{a}$ T., "Arte y devoción en las Hermandades penitenciales mercedarias de la provincia de Sevilla", op. cit., p. 75.

32 RUIZ BARRERA, M. ${ }^{a}$ T., "La Merced en los"Pasos" penitenciales. Algunos ejemplos en Andalucía Occidental", op. cit., p. 587.

33 GARCÍA DE LA CONCHA, F., "Muy Antigua y Fervorosa Hermandad y Cofradía de Nuestro Padre Jesús Nazareno, María Santísima del Mayor Dolor y San Juan Evangelista, de El Viso del Alcor", en J. SÁNCHEZ HERRERO, J. RODA PEÑA y F. GARCÍA DE LA CONCHA DELGADO (coord.). Nazarenos de Sevilla, op. cit., 
Nazareno es de Andrés Cansino (1669) al que se le atribuye también la buena figura de Simón de Cirene que le acompaña camino del Calvario. La Virgen del Mayor Dolor es anónima imagen de candelero fechable en el tránsito de los siglos XVII y XVIII ${ }^{34}$.

Supone la corporación con un mayor número de enseres con temática mercedaria y la que presenta mayor variedad iconográfica. En orfebrería destacamos una pequeña imagen de la Virgen de la Merced hodegetria, obra de 1997 del Taller Villarreal (con diseño de F. Berlanga), que preside el paso de palio. Es una copia de la que se venera en el retablo mayor ${ }^{35}$, excelente talla en madera de pino de Flandes de principios del siglo XVII y reformada posiblemente por Juan Cano en la siguiente centuria ${ }^{36}$. Corona el banderín otra copia mariana, realizada en 2008 por Talleres de Orfebrería Amores de La Algaba (Sevilla) ${ }^{37}$.

La renovación del paso de misterio por Julián Sánchez Medina comprendida entre 2006 y $2008^{38}$, llevó a todo un completo programa iconográfico con una evidente simbología referente a la vinculación histórica de la hermandad con la orden descalza. En las esquinas se aprecian pequeñas efigies de bulto redondo, talladas en pino de Flandes por José María Leal Bernáldez en 2008, con gran

t. III, p. 321. Se titula de Nuestra Señora de la Merced desde 2001, El Nazareno. Boletín 19 (2001), 3. La agregación a la orden se logró en 8 de marzo de 2015.

34 GARCÍA DE LA CONCHA DELGADO, Federico, "Muy Antigua y Fervorosa Hermandad y Cofradía de Nuestro Padre Jesús Nazareno, María Santísima del Mayor Dolor y San Juan Evangelista", en SÁNCHEZ HERRERO, J., J. RODA PEÑA y F. GARCÍA DE LA CONCHA DELGADO (coord.). Nazarenos de Sevilla, op. cit., T. III, pp. 312. 318-319.

35 RUIZ BARRERA, M. T.: La Virgen de la Merced. Iconografía en Sevilla, op. cit., p. 70; ID., Descubriendo Andalucía. El arte mercedario en Sevilla, op. cit., p. 95. ID., "La Merced en los"Pasos" penitenciales. Algunos ejemplos en Andalucía Occidental”, op. cit., p. 576.

36 F. DE LA VILLA NOGALES, Fernando y Esteban MIRA CABALLO, Documentos inéditos para la Historia del Arte en la provincia de Sevilla, siglos XVI al XVIII. Sevilla 1993, pp. 54-55. 69-72; El estudio iconográfico de la Virgen puede consultarse en RUIZ BARRERA, M. ${ }^{a}$ T., La Virgen de la Merced. Iconografía en Sevilla, op. cit., p. 58, lám. 3; ID., Descubriendo Andalucía. El arte mercedario en Sevilla, op. cit., p. 84.

37 El Nazareno 34 (2008) 18. El Nazareno. Boletín 34 (2008), 18; RUIZ BARRERA, M. ${ }^{a}$ T., "Arte y devoción en las Hermandades penitenciales mercedarias de la provincia de Sevilla", en Morón Cofrade 13 (2010) 75. ID.,"La Merced en los"Pasos" penitenciales. Algunos ejemplos en Andalucía Occidental”, op. cit., pp. 576. 581.

El Nazareno 30 (2006) 10. 
minuciosidad formal y detallismo en los ricos y coloristas estofados que representan a los cuatro santos expuestos en el retablo mayor: san Pedro Nolasco - Patrón de El Viso del Alcor desde 1630 -, san Ramón Nonato y san Serapio a los que se une san Lorenzo (atribuidas a Juan Cano, h. 1760-1762) ${ }^{39}$. Sostienen los mismos atributos que en el retablo, pero labrados en plata por Talleres deVillarreal en el año 2008. San Pedro Nolasco, como fundador porta estandarte, y también grilletes rotos en alusión al carácter redentor de la orden; ostensorio y evangelios son los atributos de san Ramón Nonato; san Serapio y san Lorenzo sostienen sus respectivos símbolos de martirio, la cruz en aspas y la parrilla. Las capillitas laterales, del mismo autor, presentan altorrelieves tallados igualmente en pino de Flandes, estofado y policromado, representando las relaciones históricas de la hermandad con la localidad y su religiosidad. Nos interesa la que representa la entrega del Niño Jesús a san Cayetano por la Virgen, que presenta los rasgos de la imagen de Nuestra Señora de la Merced que preside el retablo mayor ${ }^{40}$.

Por último, en 2016 la hermandad realizó un relicario, obra de Pedro Rodríguez, para depositar las reliquias encontradas en el ara del altar mayor en noviembre de 2014, presuntamente pertenecientes a san Pedro Nolasco, nombre que figura en los papeles que cubrían los fragmentos de los restos óseos. El relicario, en metal plateado, exhibe un escudo mercedario, el de UrbanoVIII - pontífice que canonizó en 1628 a Nolasco -, el de la Casa de Castellar - promotora de la reforma mercedaria y del convento de El Viso - así como, el de la propia hermandad. Orna la base la visión de la oliva o alegoría de la

39 DE LA VILLA NOGALES, F. y E. MIRA CABALLO, Documentos inéditos para la Historia del Arte en la provincia de Sevilla, siglos XVI al XVIII, op. cit., pp. 5455. HALCÓN ÁLVAREZ-OSORIO, Fátima, Francisco J. HERRERA GARCÍA y Álvaro RECIO MIR, El retablo barroco sevillano. Sevilla 2000, p. 502; El estudio estilístico e iconográfico del retablo e imágenes de santos puede consultarse en RUIZ BARRERA, M. ${ }^{a}$ Teresa, Los Santos de la Merced. Aproximación a su iconografía en Sevilla en, Analecta Mercedaria n $24-25$ (2005-2006) 67. 132. 176. ID., Descubriendo Andalucía. El arte mercedario en Sevilla, op. cit., pp. 163. 220. 228. MARTÍN ROLDÁN, Á., El Nazareno. Boletín. 34 (2008) 21-22; RUIZ BARRERA, M. ${ }^{a}$ T., "Arte y devoción en las Hermandades penitenciales mercedarias de la provincia de Sevilla”, op. cit., pp. 74-75. ID., "La Merced en los"Pasos" penitenciales. Algunos ejemplos en Andalucía Occidental", op. cit., p. 578.

40 El Nazareno. 30 (2006) 10. El Nazareno 33 (2007) 26. MARTÍN ROLDÁN, Ángel, El Nazareno 34 (2008) 21-22. 


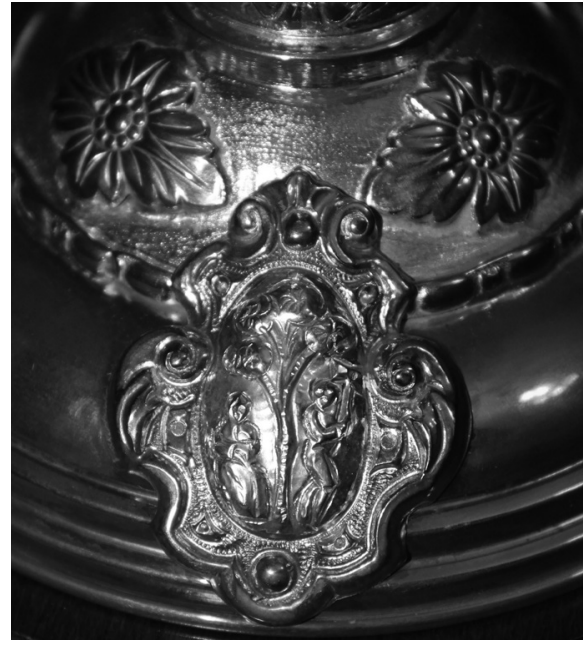

Lámina 4. El Viso del Alcor. Hermandad de Nuestro Padre Jesús Nazareno y María Santísima del Mayor Dolor y Traspaso. Visión de la Oliva. Pedro Rodríguez. 2014.

fundación descalza según un sueño del patriarca Nolasco $(\text { Lám. } 4)^{41}$. En él, el joven seglar antes de fundar la orden, vio un olivo frondoso y unos individuos que deseaban podarlo, pero mientras cortaban ramas otras nuevas nacían ${ }^{42}$. La Merced ve en esta «milagrosa visión» la fortaleza y vida de la orden a fundar. Por su parte, la reforma mercedaria o descalcez, identificó esta visión con la premonición de su origen, según fray Pedro de San Cecilio en sus Anales de los Descalzos de la Merced ${ }^{43}$.

El escudo mercedario luce en la toca de sobremanto bordada en hilo de oro por Carrasquilla a principios de la década de 1980 junto con el de san Juan, así como en la bambalina trasera del palio, obra de Jesús Rosado, de 1999 bordado a base de oro fino y distintas técnicas ${ }^{44}$. Miguel Ángel Crespo Martín en 2003 realizó el escudo de la Merced acompañando a la Cruz de Jerusalén bordado en el banderín de la Banda de Cornetas y Tambores «Nuestra Señora de la Merced». Entre las joyas es de destacar el escudo de la orden que donara un hermano en forma de broche en oro para la salida procesional de María Santísima del Mayor Dolor ${ }^{45}$.

41 Información oral / jueves, 26 de mayo de 2016.

42 TIRSO DE MOLINA, Historia General de la Orden de Nuestra Señora de las Mercedes. I edición crítica por Manuel Penedo Reyes, O. de M., Madrid, 1973, T. I, pp. 89-90. GAZULLA, Faustino, O. de M., La Orden de Ntra. Sra. de la Merced. Estudios históricos-críticos (1218-1317) (Barcelona, 1934) Valencia, 1985, p. 50.

43 SAN CECILIO, Pedro de, O.M.D., Annales del Orden de Descalzos de Ntra. Sra. de la Merced Redempcion de Cautivos. (Barcelona 1669). Madrid, 1985, T. I, pp. 3-10.

44 BONILLA CRUZ, Francisco Javier, "Entrevista al bordador ecijano don Jesús Rosado Borja", en El Nazareno 19 (2001) 20-21.

45 RUIZ BARRERA, M. ${ }^{a}$ T., "Arte y devoción en las Hermandades penitenciales mercedarias de la provincia de Sevilla", op. cit., pp. 74-75. 


\subsection{Marchena. «Real Hermandad Mercedaria de Nuestro Padre Jesús de la Paz en su Entrada Triunfal en Jerusalén y María Santísima de la Palma»}

La corporación tuvo su origen en 1956 en el convento de san Agustín, regentado por mercedarios descalzos desde $1915^{46}$. María Santísima de la Palma es anónima imagen de candelero, del siglo XVII ${ }^{47}$. Nuestro Padre Jesús de la Paz es talla de Manuel Martín Nieto (2000).

El «paso» de palio - de Talleres de Salteras en 1995 - está confeccionado a base de recortes de malla dorada y posee en el Gloria una representación mariana al óleo pintada por Pérez Conde en 1995, donación del grupo joven ${ }^{48}$. Representa a la Virgen vestida al uso de la orden con hábito, escapulario y capa blancas, en figura completa y posición de tres cuartos, sedente sobre nubes. Se inspira en la que pintara Francisco Pacheco en 1605 en la denominada «Aparición de la Virgen de la Merced a San Ramón Nonato», conservada en el hispalense Museo de Bellas Artes ${ }^{49}$. La heráldica de la orden luce en la bambalina frontal del paso de palio de la Virgen de la Palma, obra de 1991 por Manuel Solano ${ }^{50}$, y en el banderín bordado sobre tisú de plata, realizado por M. ${ }^{a}$ del Carmen, de Pilas, en $1993^{51}$.

46 CANO MANRIQUE, Francisco, O.M.D., La Restauración de la Orden (1886-1915), en Historia de la Orden de la Merced Descalza (s. XIX). T. II, Madrid, 1992, p. 324.

47 MAYO RODRÍGUEZ, Julio, "Hermandad de Nuestro Padre Jesús de la Paz en Entrada Triunfal en Jerusalén y María Santísima de la Palma, de la Iglesia Parroquial de San Agustín", en SÁNCHEZ HERRERO, José, José RODA PEÑA y Federico GARCÍA DE LA CONCHA DELGADO (coord.). Misterios de Sevilla. T. V. Sevilla, Tartessos, 1999, pp. 38. 42.

48 MAYO RODRÍGUEZ, J.,"Hermandad de Nuestro Padre Jesús de la Paz en Entrada Triunfal en Jerusalén y María Santísima de la Palma, de la Iglesia Parroquial de San Agustín", op. cit., T.V, p. 38.

49 RUIZ BARRERA, M. ${ }^{a}$ T., La Virgen de la Merced. Iconografía en Sevilla, op. cit., pp. 80-81; ID., Descubriendo Andalucía. El arte mercedario en Sevilla, op. cit., p. 116. ID., "La Merced en los "Pasos" penitenciales. Algunos ejemplos en Andalucía Occidental", op. cit., pp. 571.572.

50 RUIZ BARRERA, M. ${ }^{\text {a }}$ T., "Arte y devoción en las Hermandades penitenciales mercedarias de la provincia de Sevilla", op. cit., p. 76.

51 MAYO RODRÍGUEZ, J.,"Hermandad de Nuestro Padre Jesús de la Paz en Entrada Triunfal en Jerusalén y María Santísima de la Palma, de la Iglesia Parroquial de San Agustín", op. cit., T.V, p. 45. 


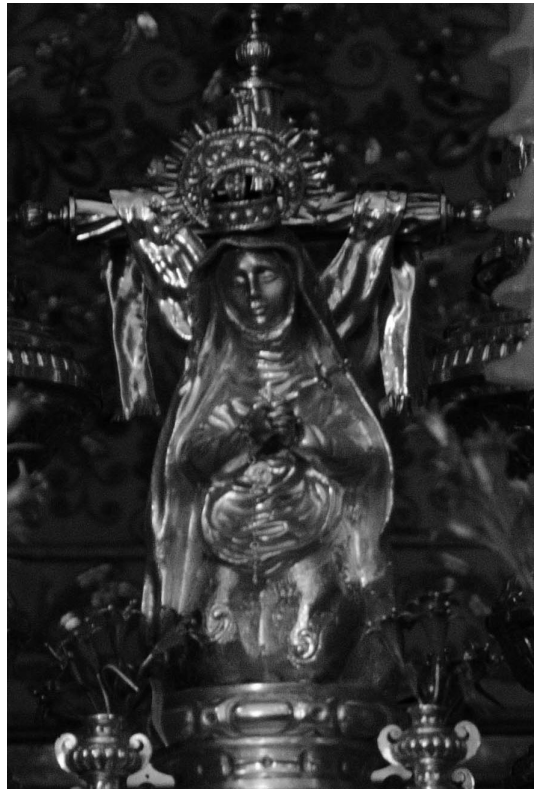

Lámina 5. Morón de la Frontera. Hermandad del Santísimo Cristo del Calvario y Nuestra Señora del Mayor Dolor. Virgen de la Merced dolorosa. Manuel de los Ríos Navarro. 1999.

\subsection{Morón de la Frontera. «Hermandad del Santísimo Cristo del Calvario y Nuestra Señora del Mayor Dolor»}

Fundada en 1958, reorganizada en 1986 y aprobada como corporación penitencial en 1990, tiene su sede en la parroquia de Nuestra Señora de la Merced, antiguo templo conventual descalzo originado en $1638^{52}$. Ambos titulares son obras de Francisco Reyes Villadiego, respectivamente ejecutadas en 1989 y $1988^{53}$. Para la salida procesional de 1999 se ejecutó por Manuel de los Ríos Navarro una interesante representación de la Virgen de la Merced como Dolorosa, que luce en la entrecalle del «paso» de palio, recordando así a la antigua Virgen que con esa advocación procesionaba en los años setenta del siglo XX (Lám. 5) ${ }^{54}$. Posee el emblema mercedario bordado en la delantera del palio, obra de Manuel Solano, entre 1994 y 1998, y en el banderín realizado en oro fino sobre tisú de plata por el propio Taller de la Hermandad, en $1996^{55}$.

52 PÉREZ GONZÁLEZ, Silvia, "Hermandad del Santísimo Cristo del Calvario y Nuestra Señora del Mayor Dolor" en SÁNCHEZ HERRERO, José, José RODA PEÑA y Federico GARCÍA DE LA CONCHA DELGADO (coord.). Crucificados de Sevilla, T. IV. Sevilla, Tartessos, 2002, pp. 108-109.

53 PÉREZ GONZÁLEZ, S. "Hermandad del Santísimo Cristo del Calvario y Nuestra Señora del Mayor Dolor", op. cit., T. IV, pp. 110-111. https://consejomoron.org/ hermandad-del-calvario/

54 Mide $24 \mathrm{~cm}$. El boceto es de Francisco Reyes Villadiego. Revista Confraternitas, julio 2005. RUIZ BARRERA, M. ${ }^{a}$ T., "La Merced en los "Pasos" penitenciales. Algunos ejemplos en Andalucía Occidental", op. cit., p. 586. La fotografía es de Juan Manuel Guardado, cedida por la Revista Morón Cofrade.

55 PÉREZ GONZÁLEZ, S., "Hermandad del Santísimo Cristo del Calvario y Nuestra Señora del Mayor Dolor", en SÁNCHEZ HERRERO, J., J. RODA PEÑA y F. 


\section{HERMANDADES CON TEMÁTICA MERCEDARIA EN SU PATRIMONIO ARTÍSTICO, PERO SIN RELACIÓN CON LA ORDEN}

\subsection{Benacazón. «Hermandad y Cofradía del Santísimo Cristo de la Vera Cruz y María Santísima de los Dolores»}

La corporación penitencial se originó a principios del siglo XVI, pues existía en 1511, fecha de sus primeras reglas. La antigua ermita de la Veracruz se reconstruyó hacia $1965^{56}$. La imagen cristífera es de autoría anónima y fechable a principios de la decimosexta centuria mientras que la dolorosa es también anónima, pero se adscribe al círculo de Cristóbal Ramos, de finales del siglo XVIII.

En la época de la reconstrucción de la ermita se realizó también la moderna portada. Esta se adorna con veinticuatro retablos cerámicos que representan a diversas advocaciones marianas y hagiográficas. Entre las primeras se encuentra Nuestra Señora de las Mercedes Coronada de la Puerta Real, cotitular de la hermandad de Gloria de Sevilla, donación de unos devotos ${ }^{57}$.

\subsection{Estepa. «Pontificia y Real Hermandad de San Pedro Apóstol, Santo Cristo de las Penas y María Santísima de los Dolores»}

Con sede en la iglesia parroquial de Nuestra Señora de la Asunción se reorganizó en 1933 y en $1953^{58}$, ahondando su origen en el siglo XVI. Los titulares son san Pedro Apóstol, atribuido a Pedro de Mena

GARCÍA DE LA CONCHA DELGADO, Crucificados de Sevilla, op. cit., pp. 108113. Agradezco la información al bordador don Manuel Solano, RUIZ BARRERA, M. ${ }^{a}$ T., "Arte y devoción en las Hermandades penitenciales mercedarias de la provincia de Sevilla", op. cit., p. 76. ID., "La Merced en los"Pasos" penitenciales. Algunos ejemplos en Andalucía Occidental", op. cit., p. 576.

56 PÉREZ GONZÁLEZ, Silvia, "Hermandad y Cofradía del Santísimo Cristo de la Vera Cruz y María Santísima de los Dolores", en SÁNCHEZ HERRERO, José, José RODA PEÑA y Federico GARCÍA DE LA CONCHA DELGADO (coord.). Crucificados de Sevilla, op. cit., T. III, pp. 137. 139. 142.

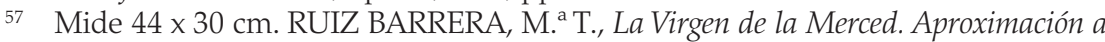
su iconografía en Sevilla, op. cit., p. 88. ID., Descubriendo Andalucía. El arte mercedario en Sevilla, op. cit., p. 78.

58 PÉREZ RUIZ, Antonio, "Pontificia y Real Hermandad de San Pedro Apóstol, Santo Cristo de las Penas y María Santísima de los Dolores, de la Iglesia parroquial de Nuestra Señora de la Asunción de Estepa", en SÁNCHEZ HERRERO, 


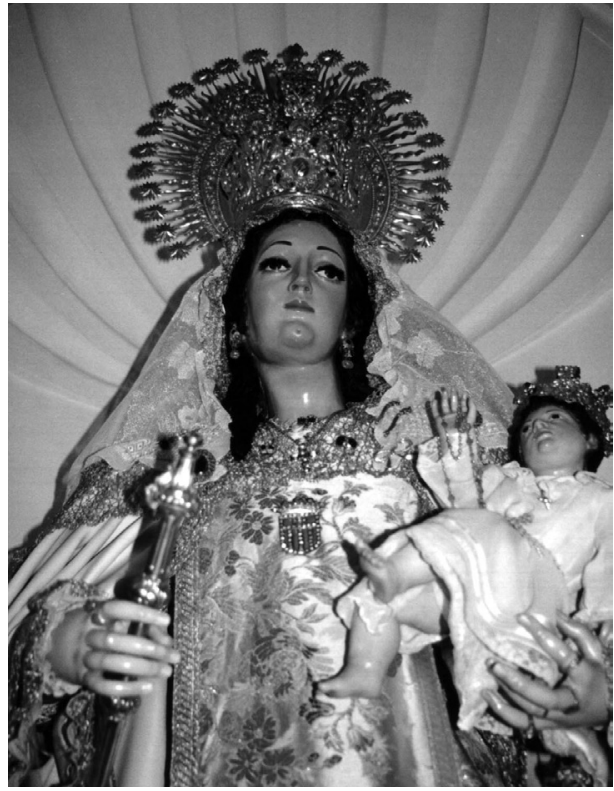

Lámina 6. Estepa. Hermandad de San Pedro Apóstol, Santo Cristo de las Penas y María Santísima de los Dolores. Virgen de la Merced hodegetria. Francisco Berlanga, 1994.

y que debió realizarse entre 1675-167859; la Virgen de los Dolores, anónima imagen de finales del siglo XVIII ${ }^{60}$; y el Cristo de las Penas, que se conserva en la iglesia de Nuestra Señora del Carmen ${ }^{61}$.

$\mathrm{Su}$ relación con la Merced estriba en honrar a las Esclavas Mercedarias del Santísimo Sacramento establecidas en Estepa en dos ocasiones, entre 1883 y 1887 y desde 1973 hasta 2010, año en que se vieron obligadas a cerrar la comunidad y residencia de ancianos que regentaban ${ }^{62}$. Así se recordaría su presencia y no se interrumpiría la devoción a Nuestra Señora de la Merced, que había ido calando hondo entre los estepeños a lo largo de los años ${ }^{63}$. Posee en los respiraderos del paso de palio una

José, José RODA PEÑA y Federico GARCÍA DE LA CONCHA (coord.), en Misterios de Sevilla. Sevilla, Tartessos, 1999, T. IV, pp. 206-209.

59 GARCÍA LUQUE, Manuel, “Nuevas esculturas de Pedro de Mena en Córdoba y Estepa”, en Archivo Español de Arte, LXXXIX, 354, abril-junio 2016, pp. 205-206.

60 DÍAZ FERNÁNDEZ, Ezequiel, "La capilla de San Pedro Apóstol de la Iglesia de Nuestra Señora de la Asunción de Estepa: aproximación a su estudio históricoartístico", en III Jornadas de Historia sobre el Provincia de Sevilla Sierra Sur. Sevilla, Asociación Provincial Sevillana de Cronistas e Investigadores Locales, 2006, pp. 280-281.

61 PÉREZ RUIZ, A., “Pontificia y Real Hermandad de San Pedro Apóstol, Santo Cristo de las Penas y María Santísima de los Dolores, de la Iglesia parroquial de Nuestra Señora de la Asunción de Estepa", op. cit., t. IV, p. 213.

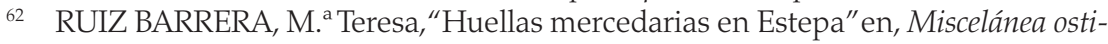
pense. Estudios sobre Historia de Estepa. A cargo de Jorge Alberto Jordán Fernández. Biblioteca de temas estepeños. Estepa, 2013.

63 RUIZ BARRERA, Ma . T., La Virgen de la Merced. Iconografía en Sevilla, op. cit., pp. 50. 72; ID., "Arte y devoción en las Hermandades penitenciales mercedarias de la 
representación de la Virgen de la Merced como Madre Hodegetria, realizada por el Taller de Hijos de Juan Fernández, entre 1988 y 1998, en chapado en latón dorado, oro fino y estofado siguiendo un modelo de Francisco Berlanga ${ }^{64}$.

Las religiosas, ante su marcha, cedieron la imagen que tenían en su oratorio, encargada en 1994 a Francisco Berlanga (Lám. 6). Es una imagen de candelero vestida al uso de la orden. La cabeza se gira levemente hacia la izquierda. El rostro presenta cabellera tallada, ojos grandes, pestañas postizas, nariz recta, labios cerrados y finos, y pronunciada barbilla con un leve hoyuelo en ella, mostrando el buen hacer escultórico del autor. El Niño, como es habitual, es de talla completa ${ }^{65}$. En la actualidad se venera en el presbiterio de la iglesia de Nuestra Señora de la Asunción, siendo responsable de ella la hermandad de san Pedro Apóstol ${ }^{66}$.

\section{CONCLUSIONES}

De las diez hermandades expuestas ocho son las que tienen una relación directa con las órdenes mercedaria y mercedaria descalza, bien por su nacimiento en los antiguos o modernos conventos bien por haber escogido a la Virgen de la Merced como su cotitular con algunas variaciones en la nomenclatura de la advocación.

Se representa la temática mercedaria en multitud de piezas que componen el ajuar de dichas hermandades, siendo el escudo el símbolo más representativo porque en la mayoría de los casos se incluye en el corporativo de cada una de ellas. Así, forma parte de piezas importantes del ajuar procesional como los ciriales, las varas de presidencia, los candelabros... y también se incluye en los programas iconográficos u ornamentales de algunos de los pasos procesionales. A más de la temática heráldica también son importantes, aunque cuantitativamente de menor entidad, la temática mariana y la

provincia de Sevilla”, op. cit., p. 76. ID., “La Merced en los “Pasos” penitenciales. Algunos ejemplos en Andalucía Occidental”, op. cit., p. 575.

64 Mide 26 × $22 \mathrm{~cm}$. RUIZ BARRERA, M. ${ }^{a}$ T., La Virgen de la Merced. Iconografía en Sevilla, op. cit., p. 71. ID., Descubriendo Andalucía. El arte mercedario en Sevilla, op. cit., p. 95. RUIZ BARRERA, M. ${ }^{a}$ T., "Huellas mercedarias en Estepa", op. cit., p. 113.

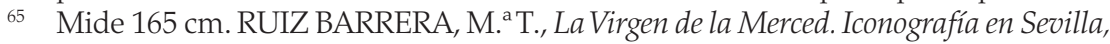
op. cit., p. 60. ID., Descubriendo Andalucía. El arte mercedario en Sevilla, op. cit., p. 86.

${ }_{66}$ RUIZ BARRERA, M. ${ }^{a}$ T., "Huellas mercedarias en Estepa”, op. cit., p. 113. 
hagiográfica. En cuanto a la diversidad de material, es la plata el más utilizado representándose en él la triple temática. Respecto a las artes, la orfebrería y el bordado son las más representativas sin obviar la imaginería o la pintura.Y por último, en cuanto se refiere a la cronología, la mayoría de las piezas se adscribe a la segunda mitad del pasado siglo y a las primeras décadas de la presente centuria. 